\title{
A canonical discriminant analysis to study the association between milk fatty acids of ruminal origin and milk fat depression in dairy cows
}

\author{
G. Conte, ${ }^{*}$ C. Dimauro,$\dagger^{1}$ A. Serra, ${ }^{*}$ N. P. P. Macciotta,$\dagger$ and M. Mele ${ }^{*}$ \\ *Department of Agriculture, Food and Environment, University of Pisa, Via del Borghetto 80, 56124 Pisa, Italy \\ †Department of Agriculture, University of Sassari, Via de Nicola 9, 07100 Sassari, Italy
}

\begin{abstract}
Although milk fat depression (MFD) has been observed and described since the beginning of the last century, all the molecular and biochemical mechanisms involved are still not completely understood. Some fatty acids (FA) originating during rumen biohydrogenation have been proposed as causative elements of MFD. However, contradictory results were obtained when studying the effect of single FA on MFD. An alternative could be the simultaneous evaluation of the effect of many FA using a multivariate approach. The aim of this study was to evaluate the relationship between individual milk FA of ruminal origin and MFD using canonical discriminant analysis, a multivariate technique able to distinguish 2 or more groups on the basis of a pool of variables. In a commercial dairy herd, a diet containing $26 \%$ starch on a DM basis induced an unintentional MFD syndrome in 14 cows out of 40. Milk yielded by these 14 animals showed a fat content lower than $50 \%$ of the ordinary value, whereas milk production and protein content were normal. The remaining 26 cows secreted typical milk fat content and therefore were considered the control group, even though they ate the same diet. The stepwise discriminant analysis selected 14 milk FA of ruminal origin most able to distinguish the 2 groups. This restricted pool of FA was used, as variables, in a run of the canonical discriminant analysis that was able to significantly discriminate between the 2 groups. Out of the $14 \mathrm{FA}, 5$ conjugated linoleic acid isomers (C18:2 trans-10,trans-12, C18:2 trans-8,trans-10, C18:2 trans-11,cis-13, C18:2 cis-9,cis-11, C18:2 cis-10,cis-12) and C15:0 iso were more related to the control group, whereas C18:2 trans-10,cis-12, C16:1 trans-6-7, C16:1 trans-9, C18:1 trans-6-8, C18:1 trans-9, C18:1 trans-10, C18:1 cis-11, and C18:3n-3 were positively associated with the MFD group, allowing a complete discrimination. On the basis of these results, we can conclude that
\end{abstract}

Received October 4, 2017.

Accepted February 26, 2018.

${ }^{1}$ Corresponding author: dimauro@uniss.it
(1) the shift of ruminal biohydrogenation from C18:1 trans-11 to C18:1 trans-10 seemed to be strongly associated with MFD; (2) at the same time, other C18:1 trans isomers showed a similar association; (3) on the contrary, conjugated linoleic acid isomers other than C18:2 trans-10,cis-12 seemed to be associated with a normal fat secretion. Results confirmed that MFD is the consequence of a combined effect of the outflow of many ruminal FA, which collectively affect mammary fat synthesis. Because the animals of the 2 groups were fed the same diet, these results suggested that factors other than diet are involved in the MFD syndrome. Feeding behavior (i.e., ability to select dietary ingredients in a total mixed ration), rumen environment and the composition of ruminal bacteria are additional factors able to modify the products of rumen biohydrogenation. Results of the present work confirmed that the multivariate approach can be a useful tool to evaluate a metabolic pathway that involves several parameters, providing interesting suggestions about the role of some FA involved in MFD. However, results about the MFD syndrome obtained in the present research require a deep molecular investigation to be confirmed.

Key words: milk fat depression, cow, biohydrogenation, discriminant analysis

\section{INTRODUCTION}

Milk fat depression (MFD) syndrome is a phenomenon characterized by a reduction of milk fat level with no change in the secretion of milk protein and lactose (Shingfield and Griinari, 2007; Harvatine et al., 2009; Bauman et al., 2011).

Reduction in milk fat synthesis is generally related to the diet composition: low forage to concentrate ratio, high starch diets, and high vegetable or marine oil supplementation (Loor et al., 2005; Alizadeh et al., 2012; Kargar et al., 2012).

In the last $20 \mathrm{yr}$, several works proposed the biohydrogenation theory as the most comprehensive one to explain MFD. According to this theory, changes in rumen lipid metabolism may result in the formation 
of specific biohydrogenation intermediates that directly inhibit milk fat synthesis. Numerous works demonstrated that some specific dietary factors may influence ruminal $\mathrm{pH}$ and the microbial population, altering the pathways of rumen biohydrogenation of dietary fatty acids (FA). These factors included type of grain (Mohammed et al., 2010), amount and type of fat supplementation (Alizadeh et al., 2012; Kargar et al., 2012), forage to concentrate ratio, and forage type (Loor et al., 2005; Kargar et al., 2012). The molecular mechanisms involved in the mammary gland metabolism are still not completely known, but several works in dairy cows demonstrated a downregulation of the expression of key genes involved in milk fat synthesis (Angulo et al., 2012; Hussein et al., 2013; Bionaz et al., 2015).

Numerous studies investigated the role of ruminal FA on MFD, with conflicting results. The C18:2 trans10, cis-12, a CLA isomer formed during the isomerization of C18:2n-6 in the rumen (Wallace et al., 2007), is the only biohydrogenation intermediate with an unequivocally demonstrated inhibitory effect on milk fat synthesis in dairy cows (Baumgard et al., 2002). Nevertheless, diet-induced MFD is a natural phenomenon able, under specific dietary compositions, to modify the pathways of rumen biohydrogenation producing FA intermediates that are potent inhibitors of milk fat synthesis (Bauman et al., 2011). The response of mammary gland to the effect of C18:2 trans-10,cis-12 is variable. The reaction is rapid to abomasal infusion (milk fat yield decreased after 14-60 h; Harvatine and Bauman, 2011). Also, a rapid recovery of normal milk fat was observed after the cessation of abomasal infusion of C18:2 trans-10,cis-12 (Baumgard et al., 2000). Feeding rumen-protected C18:2 trans-10,cis-12 induced a maximal decrease of milk fat yield within 1 wk of dietary intervention (Medeiros et al., 2010). On the contrary, the induction of MFD through dietary modification requires 11 to $19 \mathrm{~d}$ for complete induction (Shingfield et al., 2006) because changes in the rumen environment and a shift in the microbial population must occur to produce sufficient quantities of milk-fat-depressing intermediates to affect mammary lipid synthesis (Rico and Harvatine, 2013).

However, rumen outflow of C18:2 trans-10, cis-12 does not completely explain the decrease in milk fat synthesis in all cases of MFD, especially in small ruminants, in which a more variable response to lipid supplementation was observed (Toral et al., 2015). Moreover, increases in milk fat C18:2 trans-10, cis-12 concentrations on diets causing MFD are often lower than would be expected based on the observed enrichment in milk fat to postruminal C18:2 trans-10,cis-12 infusion, suggesting other biohydrogenation intermediates or other mechanisms may also be involved (Toral et al., 2015).
According to these findings, several authors suggested that additional biohydrogenation intermediates other than C18:2 trans-10,cis-12 should be involved in the MFD syndrome (Shingfield and Griinari, 2007; Bichi et al., 2013; Toral et al., 2015). Other CLA isomers have been also suggested as responsible for MFD, such as C18:2 trans-9,cis-11 or C18:2 cis-11,trans-13 (Roy et al., 2006; Shingfield et al., 2006). Among C18:1 trans isomers, C18:1 trans-10, originating from C18:2 trans10, cis-12, has been proposed as a repressor of mammary lipogenesis (McKain et al., 2010). In fact, Lock et al. (2007) revealed that abomasal infusion of C18:1 trans-10 has no effect on milk fat secretion. Overall, the increase of ruminal outflow of C18:1 trans-10 cannot completely explain the MFD in lactating cows (Shingfield and Griinari, 2007).

The effect of a single FA on MFD is usually evaluated by abomasal infusion. This approach allows obtaining information on the direct role of the single FA on MFD, but it does not provide any information about the pattern of rumen biohydrogenation related to the origin of a specific FA. Numerous C18:3, C18:2, and C18:1 isomers are usually produced in the rumen in the case of diet-induced MFD, and it is not possible to fully explain the observed decrease in milk fat yield by considering only one isomer (Ventto et al., 2017). So, the evaluation of MFD is very difficult because numerous variables affect the lipid metabolism.

The effect of biohydrogenation on MFD could be better evaluated by using a multivariate approach. Kadegowda et al. (2008) used principal component analysis to analyze the variability of FA composition observed in milk of cows affected by MFD. In the present work, the multivariate discriminant analysis was used to analyze the correlation structure of involved ruminal FA variables. The extracted information were used either to maximize distance between different groups or to better understand the phenomenon under study.

The main objective of this study was to develop a multivariate approach to discriminate cows affected by the MFD syndrome versus cows not affected, to identify specific milk FA patterns as potential markers of MFD.

\section{MATERIALS AND METHODS}

\section{Animals and Experimental Design}

In a commercial dairy herd located in Tuscany (Italy), 14 cows out of 40 were classified by MFD status (MFD group), since they produced milk with a $50 \%$ reduction of fat content (Griinari et al., 1998) and normal level of yield and protein, as revealed during routine milk composition analysis. The remaining 26 
cows secreted typical milk fat content and therefore were considered the control group. All the cows (milk yield: $27.56 \pm 6.21 \mathrm{~kg} / \mathrm{d}$; fat $\%: 3.10 \pm 1.0$; protein $\%$ : $3.20 \pm 0.39$; lactose \%: $4.69 \pm 0.38$; fat yield: $0.72 \pm$ $0.27 \mathrm{~kg} / \mathrm{d}$; protein yield: $0.87 \pm 0.16 \mathrm{~kg} / \mathrm{d}$; lactose: 1.30 $\pm 0.30 \mathrm{~kg} / \mathrm{d}$ ) were healthy and fed the same diet (Table 1) that contained starch and no fat supplementation, which predispose the most susceptible animals to MFD syndrome (Ramirez Ramirez et al., 2015). The diet was offered as a TMR to avoid selection of dietary components (particle size ranged between 3 and $5 \mathrm{~cm}$, estimated by a visual observation of the ration). Cows were milked twice a day, at 0700 and $1800 \mathrm{~h}$, and the daily production was recorded. Milk was sampled one time per day in the morning and 2 aliquots were collected for each sample: one was stored at $4^{\circ} \mathrm{C}$ with a preservative (bronopol solution, Lanxess, Corporation, Pittsburgh, PA) for fat and protein determination, whereas the second was stored at $-20^{\circ} \mathrm{C}$ for the analysis of FA composition. All milk analyses were performed once a week for 6 consecutive weeks.

Table 1. Formulation and chemical composition of the diet

\begin{tabular}{lr}
\hline Item & Value \\
\hline Ingredient (\% of diet) & \\
Alfalfa hay, first cut & 8.0 \\
Alfalfa hay, second cut & 20.5 \\
Corn silage & 23.7 \\
Corn grain & 11.2 \\
Barley grain & 6.7 \\
Wheat bran & 4.5 \\
Concentrate feed $^{1}$ & 25.0 \\
Mineral-vitamin supplement ${ }^{2}$ & 0.4 \\
F:C & $53: 47$ \\
Chemical composition (g/kg of diet $\left.\mathrm{DM}^{1}\right)$ & \\
Starch & 262.1 \\
Ether extract & 31.0 \\
CP & 133.8 \\
NDF & 383.4 \\
ADF & 232.3 \\
ADL & 44.9 \\
Ash & 59.6 \\
ME (Mcal/d) & 52.7 \\
MP (g/d) & $2,205.0$ \\
\hline CD
\end{tabular}

${ }^{1}$ Concentrate feed composition (\% of ingredients): corn grain (39\%), soybean meal (18\%), wheat bran (10\%), barley grain (10\%), extruded linseed (4\%), sunflower meal (15\%), beet pulp $(2 \%)$, sugar cane molasses $(2 \%)$.

${ }^{2}$ Mineral-vitamin supplement composition: $\mathrm{DM}=96.6 \%$; total carbohydrates $=2.9 \%$; proteins $=0.4 \%$; fats $=0.8 \% ; \mathrm{Ca}=32.0 \% ; \mathrm{P}=$ $3.5 \% ; \mathrm{Mg}=1.8 \% ; \mathrm{K}=0.1 \% ; \mathrm{Na}=6.8 \% ; \mathrm{Cl}=7.8 \% ; \mathrm{S}=0.3 \% ; \mathrm{Mn}=$ $2,807 \mathrm{mg} / \mathrm{kg} ; \mathrm{Cu}=396 \mathrm{mg} / \mathrm{kg} ; \mathrm{Fe}=3,896 \mathrm{mg} / \mathrm{kg} ; \mathrm{Zn}=3,860 \mathrm{mg} / \mathrm{kg} ;$ $\mathrm{I}=28 \mathrm{mg} / \mathrm{kg} ; \mathrm{Co}=14 \mathrm{mg} / \mathrm{kg} ; \mathrm{Se}=16 \mathrm{mg} / \mathrm{kg} ;$ methionine $=0.2 \%$; lysine $=0.001 \%$; threonine $=0.001 \%$; leucine $=0.002 \%$; isoleucine $=$ $0.001 \%$; valine $=0.003 \%$; phenylalanine $=0.001 \%$; vitamin $\mathrm{A}=357$ $\mathrm{mg} / \mathrm{kg}$; vitamin $\mathrm{D}_{3}=6,457 \mathrm{mg} / \mathrm{kg}$; vitamin $\mathrm{E}=1,178 \mathrm{mg} / \mathrm{kg}$; niacin $=5,434 \mathrm{mg} / \mathrm{kg} ;$ vitamin $\mathrm{B}_{1}=50 \mathrm{mg} / \mathrm{kg}$; vitamin $\mathrm{B}_{2}=110 \mathrm{mg} / \mathrm{kg}$; choline $=4,863 \mathrm{mg} / \mathrm{kg}$.

${ }^{3}$ Forage:concentrate ratio.

\section{Milk Composition and Fatty Acid Profile}

Milk composition (fat, total protein, and lactose) of the individual milk samples was determined by infrared spectrophotometry (ISO, 2013) using a MilkoScan FT6000 (Foss, Hillerød, Denmark).

Milk fat extraction and derivatization of FA were performed following the procedure described by Mele et al. (2008). Milk FA composition was determined by GC analysis using a GC2010 Shimadzu gas chromatograph (Shimadzu, Columbia, MD) equipped with a flame ionization detector and a high polar fused-silica capillary column (Chrompack CP-Sil88 Varian, Middelburg, the Netherlands; 100 m, $0.25 \mathrm{~mm}$ i.d.; film thickness 0.20 $\mathrm{mm})$. Hydrogen was used as the carrier gas at a flow of $1 \mathrm{~mL} / \mathrm{min}$. Split/splitless injector was used with a split ratio of 1:80. An aliquot of the sample was injected under the following GC conditions: the oven temperature started at $40^{\circ} \mathrm{C}$ and held at that level for 1 min; it was then increased to $173^{\circ} \mathrm{C}$ at a rate of $2^{\circ} \mathrm{C} / \mathrm{min}$, and held at that level for $30 \mathrm{~min}$, before being once again increased to $185^{\circ} \mathrm{C}$ at $1^{\circ} \mathrm{C} / \mathrm{min}$ and held for $5 \mathrm{~min}$, and then to $220^{\circ} \mathrm{C}$ at a rate of $3^{\circ} \mathrm{C} / \mathrm{min}$, and held for 19 min The injector temperature was set at $270^{\circ} \mathrm{C}$ and the detector temperature was set at $300^{\circ} \mathrm{C}$. Individual FA methyl esters were identified by comparison with a standard mixture of 52 Component FAME Mix (NuChek Prep Inc., Elysian, MN). The identification of isomers of $\mathrm{C} 18: 1$ was based on commercial standard mixtures (Supelco, Bellefonte, PA) and published isomeric profiles (Kramer et al., 2008). Nonanoic and nonadecanoic methyl esters were used as the internal standard, for short- and medium-long-chain FA, respectively. Milk FA composition was expressed as grams per $100 \mathrm{~g}$ of total lipids (TL). The level of FA desaturation was estimated by the ratio of cis-9 unsaturated to cis-9 unsaturated + saturated for specific FA, named desaturase index (DI; Mele et al., 2007).

The CLA profile in milk was determined by HPLC analysis by injecting an aliquot of FAME previously obtained for GC analysis. The HPLC system consisted of a photodiode array detector and Prostar HPLC equipment (Varian). Three silver ion columns (ChromSphere 5 Lipids column $250 \mathrm{~mm} \times 4.6 \mathrm{~mm}$, Varian) were used in series. The CLA isomers were eluted using a fresh mixture of acetonitrile $0.1 \%$ ( $\mathrm{vol} / \mathrm{vol}$ ) in hexane at a flow of $1 \mathrm{~mL} / \mathrm{min}$. The injection loop was $20 \mu \mathrm{L}$, and UV detection was performed at a wavelength of 233 $\mathrm{nm}$. Because a reliable internal standard for CLA is not yet available, the quantitative measurements were performed through a calibration curve, using highpurity individual C18:2 cis-9,trans-11 and C18:2 trans10,cis-12 CLA (Matreya Inc., Pleasant Gap, PA). The 
CLA mix standard (Sigma Chemical Co., St. Louis, $\mathrm{MO}$ ) and published isomeric profile (Kramer et al., 2004) were also used to help identify the CLA isomers in milk. The CLA isomers were expressed as milligrams per $100 \mathrm{~g}$ of TL.

\section{Statistical Analysis}

Data obtained in the present work were analyzed by using the SAS software (ver. 9.4, SAS Institute Inc., Cary, NC). Two different approaches were used for statistical analysis. First, the effect of the MFD syndrome on milk composition was analyzed by using the following mixed linear model:

$$
\begin{aligned}
\mathrm{y}_{\mathrm{ijkzmn}}= & \mathrm{MFD}_{\mathrm{i}}+\text { weeks }_{\mathrm{j}}+\mathrm{DIM}_{\mathrm{k}}+\text { parity }_{\mathrm{z}} \\
& +\operatorname{cows}_{\mathrm{m}}\left(\mathrm{MDF}_{\mathrm{i}}\right)+\mathrm{e}_{\mathrm{ijkzmn}},
\end{aligned}
$$

where $\mathrm{y}_{\mathrm{ijkzmn}}=$ milk yield, milk fat $\%$, milk protein $\%$, milk lactose $\%$, and $\mathrm{FA}$ composition; $\mathrm{MFD}_{\mathrm{i}}=$ fixed effect of the ith milk fat secretion status (control and MFD group); weeks $\mathrm{j}_{\mathrm{j}}=$ fixed effect of the jth week (1 to 6); $\mathrm{DIM}_{\mathrm{k}}=$ fixed effect of the kth days in milking class $(<100,100-200$, and $>200)$; parity $_{\mathrm{z}}=$ fixed effect of the zth parity class (primiparous, secondiparous, and pluriparous); $\operatorname{cows}_{\mathrm{m}}\left(\mathrm{MDF}_{\mathrm{i}}\right)=$ random effect of $\mathrm{mth}$ cows nested in MFD group; and $\mathrm{e}_{\mathrm{ijkzmn}}=$ random error. Covariances of random effects were structured as $\mathbf{I} \sigma^{2}$ cow and $\mathbf{I} \sigma^{2}$, where $\mathbf{I}$ is an identity matrix and $\sigma_{\text {cow }}^{2}$ and $\mathbf{I} \sigma^{2}{ }_{\mathrm{e}}$ are cow and residual variance, respectively.

The average correlation among test day records within lactation (i.e., the mean repeatability of test day values) was calculated as $\sigma_{\text {cow }}^{2} /\left(\sigma_{\text {cow }}^{2}+\sigma_{\text {e }}^{2}\right)$.

The following milk FA of ruminal origin were involved in the multivariate discriminant procedures: C18:2 trans-12,trans-14, C18:2 trans-11,trans-13, C18:2 trans-10,trans-12, C18:2 trans-9,trans-11, C18:2 trans8,trans-10, C18:2 trans-7,trans-9, C18:2 trans-11,cis-13, C18:2 trans-10,cis-12, C18:2 cis-9,trans-11, C18:2 cis11,cis-13, C18:2 cis-10,cis-12, C18:2 cis-9,cis-11, C18:2 cis-8,cis-10, C13:0 anteiso, C14:0 iso, C15:0 iso, C15:0 anteiso, C16:0 iso, C16:1 trans-7-8, C16:1 trans-9, C18:0, C18:1 trans-5, C18:1 trans-6-8, C18:1 trans -9 , C18:1 trans-10, C18:1 trans-11, C18:1 trans-12, C18:1 cis-11, C18:1 cis-12, C18:1 cis-13, C18:1 trans-16, C18:2 cis-9,trans-13, C18:2 cis-9,trans-14, C18:2 trans11,cis-15, C18:2 cis-9,cis-12, C18:3 cis-9,cis-12,cis-15, and C18:3 cis-9,trans-11,cis-15.

Three complementary techniques were used to discriminate the 2 groups: canonical discriminant analysis (CDA), stepwise discriminant analysis (SDA), and discriminant analysis (DA). The CDA is a dimension- reduction technique, related to principal component analysis and canonical correlation, able to perform both univariate and multivariate 1-way analyses. Given a classification character and several interval variables, CDA derives a set of new variables, called canonical functions (CAN), which are linear combinations of the original interval variables, as reported in the follow equation:

$$
\mathrm{CAN}=d_{1} X_{1}+d_{2} X_{2}+\ldots+d_{\mathrm{n}} X_{\mathrm{n}},
$$

where $d_{\mathrm{i}}$ are the canonical coefficients $(\mathbf{C C})$ that indicate the contribution of each variable in composing the CAN, and $X$ are the scores of the $\mathrm{n}$ original variables.

As principal components summarize the total variation in the data, CAN summarize the between-groups variation, highlighting their differences. In general, if $\mathrm{k}$ groups are involved in the study, $\mathrm{k}-1$ CAN are extracted. In the present work, having only 2 groups (control and MFD), one CAN was extracted. The effective separation between groups was assessed by using the Mahalanobis distance and the corresponding Hotelling's T-square test (De Maesschalck et al., 2000). Briefly, the Mahalanobis distance takes into account the variable co-variances in calculating distances between individuals in a multivariate vector space. The ordinary Euclidean distance is a special case of the Mahalanobis distance when variables have equal variances and zero covariances. The Hotelling's T-square test is an extension of the Student's $t$-test to the multivariate domain (Mardia, 1975).

The minimum number of FA able to discriminate the 2 groups was obtained by using the SDA, a statistical technique specifically conceived to select the subset of variables that better separate groups. The SDA was applied to the 37 milk FA of ruminal origin separately by each week and, at each run, the most discriminant FA were selected and used for CDA and DA.

The ability of CAN to assign each animal to the 2 groups was calculated as the percent of correct assignment using the DA (Mardia et al., 2000). In practice, the CAN is applied to each animal, thus obtaining a value called discriminant score. Then, the centroids of the 2 groups are calculated and, for each individual, distances from the 2 centroids are evaluated. One animal is assigned to the MFD or control group on the basis of the lowest distance from the 2 group centroids (Mardia et al., 2000).

The complete set of data was split in 6 data sets, one for each week of observation. The discriminant procedure was applied separately to the 6 data sets to test the hypothesis that FA are able to highlight the 2 groups in different periods. 


\section{RESULTS}

\section{Milk Composition and Yield}

Milk production and composition are reported in Table 2. Fat content decreased significantly, decreasing by more than $50 \%$, with no change in the milk yield, protein, and lactose. This situation was observed in all 6 wk of the trial (Figure 1). However, no significant differences were observed between the weeks. Differences observed for milk traits agreed with other studies, which revealed a reduction of milk fat with no change in the milk production, milk protein, and lactose (Roy et al., 2006; Shingfield et al., 2006), confirming the possible MFD status of cows classified in the MFD group.

\section{Milk Fatty Acid Composition}

Milk FA composition is presented in Table 2. Milk from cows in MFD status was significantly lower in SFA $(-10 \%)$ and higher in both MUFA $(+12.7 \%)$ and PUFA $(+24 \%)$ when compared with milk from the control group. Almost all the milk SFA were significantly lower in milk than the MFD group: C4:0 (-19\%), C6:0 $(-25 \%), \mathrm{C} 8: 0(-28 \%), \mathrm{C} 10: 0(-20 \%), \mathrm{C} 16: 0(-8 \%)$, C18:0 (-29\%), C20:0 (-27\%), and C24:0 (-22\%). The higher content of MUFA in milk from MFD cows was mainly related to trans FA:C16:1 trans-6-7 $(+33 \%)$, C16:1 trans-9 (+32\%), C18:1 trans-5 (+41\%), C18:1 trans-6-8 (+97\%), C18:1 trans-9 $(+79 \%), \mathrm{C} 18: 1$ trans -10 $(+421 \%)$, and $\mathrm{C} 18: 1$ trans $-12(+49 \%)$. On the contrary, the content of $\mathrm{C} 18: 1$ trans-11 and C18:1 trans-16 did not show any significant difference. In addition to trans FA, the content of $\mathrm{C} 14: 1$ cis-9, C16:1 cis-9, C17:1 cis-9, and C18:1c11 was also significantly higher in milk from the MFD group, whereas the content of C10:1 cis-9 and C18:1 cis-9 was higher in milk from the control group.

The values of DI of myristoleic to myristic, palmitoleic to palmitic, and oleic to stearic were significantly higher in milk from MFD cows (Table 2).

Milk from MFD cows showed a lower content of branched-chain fatty acids (BCFA) iso $(-10.5 \%)$ and a higher content of odd-chain fatty acids (OCFA; $+13.0 \%$ ), whereas no effects were observed for the content of BCFA anteiso.

The profile of CLA isomers of milk from MFD cows was significantly different from the control group (Table 2). The content of most of the CLA isomers was significantly higher in milk from MFD cows: C18:2 trans-12,trans-14 (+1.91 fold), C18:2 trans-11,trans-13 (+1.68 fold), C18:2 trans-9,trans-11 ( +1.66 fold), C18:2 trans-10, cis-12 (+5.11 fold), C18:2 trans- 7 , cis- $9(+1.50$ fold), C18:2 cis-11,cis-13 (+1.61 fold), and C18:2 cis-
8, cis-10 (+2.19 fold), except for C18:2 trans-10,trans-12 $(-1.41$ fold) and C18:2 cis-9,trans-11 ( -1.30 fold).

\section{Heritabilities of Milk Composition}

Heritabilities for milk composition and individual FA are shown in Table 2. Moderate heritabilities were estimated for fat and lactose, whereas a higher value was observed for protein level.

High levels of heritability $(>0.20)$ were estimated for FA directly involved in mammary gland metabolism (all SCFA, C14:0, C16:0, C18:0 C14:1 cis-9, C16:1 cis9, C18:1 cis-9, and C20:4n-6). High heritability was also observed for all DI: 0.29, 0.27, and 0.19 for DI_14 $[\mathrm{C} 14: 1$ cis-9/(C14:1 cis-9 + C14:0)], DI_16 [C16:1 cis9/(C16:1 cis-9 + C16:0)], and DI_18 [C18:1 cis-9/ (C18:0 + C18:1 cis-9)], respectively.

On the contrary, low values were estimated for $\mathrm{FA}$ deriving from the rumen such as BCFA, OCFA, and CLA isomers. Finally, a moderate heritability was estimated for C18:1 trans isomers, ranging from 0.11 for C18:1 trans-12 to 0.19 for C18:1 trans-9.

\section{Multivariate Analysis of Ruminal Milk Fatty Acids}

The SDA selected the following most discriminant 14 FA: C18:2 trans-10,trans-12, C18:2 trans-8,trans-10, C18:2 trans-11,cis-13, C18:2 trans-10,cis-12, C18:2 cis10,cis-12, C18:2 cis-9,cis-11, C15:0 iso, C16:1 trans-6-7, C16:1 trans-9, C18:1 trans-6-8, C18:1 trans-9, C18:1 trans-10, C18:1 cis-11, C18:3n-3 (Table 3).

The CDA was applied to the 14 selected FA for each of the 6 wk. In all cases, the extracted CAN significantly discriminated the 2 groups ( $P$-value Hotelling's $t$-test $<$ 0.0001). An example is shown in Figure 2, which reports scores of the canonical variables calculated for wk 2 and 4. The 2 groups, control and MFD, are clearly separated in both weeks. Their different relative positions (i.e., the MFD group was in the negative and positive side of the graph in wk 2 and 4 , respectively) are due to an algebraic effect that is a quite common event when multivariate statistics are carried out on different data sets (Macciotta et al., 2017). It can clearly be seen in Table 3, where the patterns of CC across the $6 \mathrm{wk}$ are reported. The absolute values for the different FA are consistent across the $6 \mathrm{wk}$. In the first $2 \mathrm{wk}$ and in the last one, cows of control and MFD groups showed positive and negative values of CAN, respectively, whereas in the 3rd, 4th and 5th wk we observed the opposite situation (Figure 2).

Based on these discriminations, the FA can be divided in 2 groups. The first group contained the follow- 
CONTE ET AL.

Table 2. Milk fatty acid composition of control and milk fat depression (MFD) cows ${ }^{1}$

\begin{tabular}{|c|c|c|c|c|c|c|}
\hline Item & $\begin{array}{c}\text { Control } \\
(\mathrm{n}=24)\end{array}$ & $\begin{array}{c}\text { MFD } \\
(\mathrm{n}=16)\end{array}$ & SEM & $P$-value & $\operatorname{Rep}(\%)$ & $\mathrm{h}^{2}$ \\
\hline \multicolumn{7}{|c|}{ Milk yield and chemical composition } \\
\hline Milk yield (kg) & 24.71 & 25.54 & 2.64 & 0.645 & 54.54 & 0.14 \\
\hline Fat $(\%)$ & 3.56 & 1.73 & 0.70 & $<0.001$ & 30.92 & 0.15 \\
\hline Protein $(\%)$ & 3.27 & 3.25 & 0.05 & 0.673 & 71.11 & 0.21 \\
\hline Lactose (\%) & 4.79 & 4.81 & 0.06 & 0.632 & 19.76 & 0.19 \\
\hline Fat $(\mathrm{kg})$ & 0.87 & 0.47 & 0.04 & $<0.001$ & 34.36 & 0.19 \\
\hline Protein (kg) & 1.08 & 1.07 & 0.02 & 0.673 & 53.09 & 0.22 \\
\hline Lactose $(\mathrm{kg})$ & 0.77 & 0.75 & 0.03 & 0.194 & 43.44 & 0.09 \\
\hline \multicolumn{7}{|l|}{ SFA $(g / 100 \mathrm{~g}$ of TL) } \\
\hline $\mathrm{C} 4: 0$ & 2.30 & 1.87 & 0.07 & $<0.001$ & 34.18 & 0.20 \\
\hline $\mathrm{C} 5: 0$ & 0.03 & 0.03 & 0.00 & 0.671 & 12.20 & 0.07 \\
\hline C6:0 & 1.45 & 1.09 & 0.04 & $<0.001$ & 30.91 & 0.27 \\
\hline $\mathrm{C} 7: 0$ & 0.02 & 0.02 & 0.00 & 0.779 & 9.01 & 0.01 \\
\hline C8:0 & 0.81 & 0.59 & 0.02 & $<0.001$ & 31.34 & 0.26 \\
\hline C10:0 & 1.89 & 1.52 & 0.06 & $<0.001$ & 37.52 & 0.29 \\
\hline C11:0 & 0.04 & 0.04 & 0.01 & 0.687 & 0.05 & 0.10 \\
\hline C12:0 & 2.28 & 2.14 & 0.07 & 0.276 & 36.72 & 0.23 \\
\hline $\mathrm{C} 13: 0$ anteiso & 0.04 & 0.05 & 0.00 & 0.232 & 16.03 & 0.19 \\
\hline C13:0 & 0.09 & 0.12 & 0.00 & 0.082 & 21.17 & 0.03 \\
\hline C14:0 iso & 0.07 & 0.05 & 0.00 & $<0.001$ & 32.12 & 0.01 \\
\hline C14:0 & 11.02 & 10.95 & 0.23 & 0.879 & 29.51 & 0.27 \\
\hline C15:0 anteiso & 0.54 & 0.53 & 0.02 & 0.688 & 18.61 & 0.01 \\
\hline $\mathrm{C} 15: 0$ iso & 0.20 & 0.16 & 0.01 & $<0.001$ & 26.49 & 0.04 \\
\hline C15:0 & 1.30 & 1.65 & 0.05 & $<0.001$ & 19.55 & 0.01 \\
\hline $\mathrm{C} 16: 0$ iso & 0.22 & 0.19 & 0.01 & 0.035 & 25.62 & 0.03 \\
\hline C16:0 & 29.85 & 27.36 & 0.61 & 0.008 & 46.19 & 0.26 \\
\hline $\mathrm{C} 17: 0$ iso & 0.57 & 0.56 & 0.02 & 0.844 & 15.02 & 0.04 \\
\hline $\mathrm{C} 17: 0$ anteiso & 0.61 & 0.69 & 0.02 & 0.005 & 37.80 & 0.05 \\
\hline $\mathrm{C} 17: 0$ & 0.70 & 0.75 & 0.02 & 0.167 & 29.38 & 0.05 \\
\hline C18:0 & 8.06 & 5.68 & 0.32 & $<0.001$ & 41.64 & 0.29 \\
\hline C20:0 & 0.14 & 0.10 & 0.01 & $<0.001$ & 34.94 & 0.14 \\
\hline C24:0 & 0.03 & 0.03 & 0.00 & 0.004 & 24.65 & 0.06 \\
\hline \multicolumn{7}{|l|}{ MUFA ( $\mathrm{g} / 100 \mathrm{~g}$ of $\mathrm{TL})$} \\
\hline $\mathrm{C} 10: 1$ cis-9 & 0.16 & 0.11 & 0.01 & $<0.001$ & 23.17 & 0.15 \\
\hline C12:1 cis-9 & 0.05 & 0.05 & 0.00 & 0.981 & 19.80 & 0.16 \\
\hline C14:1 cis-9 & 1.13 & 1.80 & 0.08 & $<0.001$ & 68.37 & 0.28 \\
\hline C16:1 cis-9 & 1.83 & 2.23 & 0.10 & 0.007 & 67.47 & 0.29 \\
\hline C16:1 trans- $6-7$ & 0.03 & 0.05 & 0.00 & 0.029 & 1.93 & 0.03 \\
\hline C16:1 trans-9 & 0.05 & 0.07 & 0.00 & $<0.001$ & 35.15 & 0.15 \\
\hline $\mathrm{C} 17: 1$ cis-9 & 0.34 & 0.42 & 0.02 & 0.009 & 48.78 & 0.14 \\
\hline C18:1 trans-5 & 0.02 & 0.02 & 0.00 & $<0.001$ & 26.89 & 0.15 \\
\hline C18:1 trans- $6-8$ & 0.34 & 0.67 & 0.02 & $<0.001$ & 31.09 & 0.18 \\
\hline C18:1 trans-9 & 0.27 & 0.49 & 0.02 & $<0.001$ & 23.63 & 0.19 \\
\hline $\mathrm{C} 18: 1$ trans -10 & 1.08 & 5.62 & 0.37 & $<0.001$ & 37.17 & 0.14 \\
\hline C18:1 trans-11 & 1.15 & 1.23 & 0.05 & 0.291 & 37.20 & 0.13 \\
\hline C18:1 trans -12 & 0.61 & 0.91 & 0.06 & $<0.001$ & 2.19 & 0.11 \\
\hline C18:1 cis-9 & 22.80 & 20.27 & 0.64 & 0.021 & 48.19 & 0.25 \\
\hline C18:1 cis-11 & 1.01 & 1.43 & 0.04 & $<0.001$ & 15.65 & 0.19 \\
\hline C18:1 cis-12 & 0.41 & 0.46 & 0.03 & 0.221 & 28.49 & 0.03 \\
\hline C18:1 cis-13 & 0.11 & 0.15 & 0.01 & 0.017 & 17.64 & 0.05 \\
\hline $\mathrm{C} 18: 1$ trans -16 & 0.40 & 0.45 & 0.02 & 0.112 & 28.95 & 0.12 \\
\hline \multicolumn{7}{|l|}{ PUFA $(\mathrm{g} / 100 \mathrm{~g}$ of $\mathrm{TL})$} \\
\hline C18:2 cis-9,trans-13 & 0.14 & 0.21 & 0.01 & $<0.001$ & 9.48 & 0.01 \\
\hline C18:2 cis-9,trans-14 & 0.07 & 0.09 & 0.00 & 0.004 & 0.19 & 0.01 \\
\hline C18:2 trans- 11, cis- 15 & 0.23 & 0.51 & 0.03 & $<0.001$ & 53.55 & 0.18 \\
\hline C18:2 cis-9, cis-12 & 2.17 & 2.83 & 0.09 & $<0.001$ & 45.55 & 0.05 \\
\hline C18:3 cis-9,cis-12,cis-15 & 0.72 & 0.99 & 0.03 & $<0.001$ & 26.59 & 0.14 \\
\hline $\mathrm{C} 20: 2 \mathrm{n}-6$ & 0.03 & 0.03 & 0.00 & 0.359 & 12.17 & 0.16 \\
\hline C18:3 cis-9,trans-11,cis-15 & 0.04 & 0.03 & 0.00 & 0.006 & 5.99 & 0.11 \\
\hline C20:4n-6 & 0.18 & 0.14 & 0.00 & $<0.001$ & 28.71 & 0.23 \\
\hline $\mathrm{C} 22: 2$ & 0.02 & 0.02 & 0.00 & 0.906 & 1.74 & 0.06 \\
\hline C20:5n-3 & 0.05 & 0.04 & 0.00 & 0.098 & 8.09 & 0.01 \\
\hline $\mathrm{C} 22: 5 n-3$ & 0.12 & 0.12 & 0.00 & 0.949 & 30.81 & 0.12 \\
\hline \multicolumn{7}{|l|}{ CLA isomer (mg/100 $\mathrm{g}$ of TL) } \\
\hline C18:2 trans-12,trans-14 & 1.40 & 2.66 & 0.47 & 0.046 & 79.67 & 0.02 \\
\hline C18:2 trans- 11, trans- 13 & 7.68 & 12.91 & 1.77 & 0.009 & 84.16 & 0.02 \\
\hline
\end{tabular}


Table 2 (Continued). Milk fatty acid composition of control and milk fat depression (MFD) cows ${ }^{1}$

\begin{tabular}{|c|c|c|c|c|c|c|}
\hline Item & $\begin{array}{c}\text { Control } \\
(\mathrm{n}=24)\end{array}$ & $\begin{array}{c}\text { MFD } \\
(\mathrm{n}=16)\end{array}$ & SEM & $P$-value & $\operatorname{Rep}(\%)$ & $h^{2}$ \\
\hline $\mathrm{C} 18: 2$ trans- 10, trans- 12 & 14.30 & 10.14 & 0.90 & 0.011 & 36.93 & 0.01 \\
\hline C18:2 trans-9,trans-11 & 6.67 & 11.04 & 0.68 & $<0.001$ & 45.49 & 0.01 \\
\hline C18:2 trans -8, trans -10 & 14.42 & 13.35 & 1.50 & 0.526 & 62.80 & 0.13 \\
\hline C18:2 trans-7,trans-9 & 9.77 & 11.28 & 1.40 & 0.391 & 66.82 & 0.10 \\
\hline C18:2 trans-11,cis-13 & 7.78 & 7.32 & 1.05 & 0.729 & 68.43 & 0.02 \\
\hline C18:2 trans- 10, cis -12 & 56.82 & 290.37 & 16.77 & $<0.001$ & 59.44 & 0.08 \\
\hline C18:2 cis-9,trans-11 & 506.99 & 388.94 & 29.02 & 0.009 & 53.71 & 0.08 \\
\hline C18:2 trans- 7, cis-9 & 75.45 & 113.21 & 18.03 & 0.006 & 70.96 & 0.01 \\
\hline $\mathrm{C} 18: 2$ cis- 11, cis- 13 & 0.94 & 1.51 & 0.14 & 0.049 & 51.7 & 0.01 \\
\hline C18:2 cis- 10, cis- 12 & 1.54 & 1.90 & 0.28 & 0.393 & 73.04 & 0.01 \\
\hline $\mathrm{C} 18: 2$ cis-9,cis-11 & 0.85 & 1.42 & 0.28 & 0.127 & 75.81 & 0.01 \\
\hline $\mathrm{C} 18: 2$ cis-8, cis-10 & 0.47 & 1.03 & 0.20 & 0.041 & 82.76 & 0.04 \\
\hline \multicolumn{7}{|c|}{ Class of fatty acids (g/100 $\mathrm{g}$ of TL) } \\
\hline SFA & 62.12 & 56.04 & 0.78 & $<0.001$ & 29.47 & 0.25 \\
\hline MUFA & 31.97 & 36.61 & 0.66 & $<0.001$ & 33.80 & 0.25 \\
\hline PUFA & 4.46 & 5.87 & 0.16 & $<0.001$ & 46.44 & 0.14 \\
\hline PUFA n-6 & 3.40 & 4.37 & 0.12 & $<0.001$ & 21.22 & 0.08 \\
\hline PUFA n-3 & 1.15 & 1.68 & 0.06 & $<0.001$ & 41.22 & 0.11 \\
\hline SCFA & 6.71 & 5.28 & 0.18 & $<0.001$ & 30.89 & 0.26 \\
\hline MCFA & 51.08 & 49.92 & 0.78 & 0.379 & 38.29 & 0.25 \\
\hline LCFA & 40.33 & 42.94 & 0.85 & 0.069 & 40.22 & 0.18 \\
\hline VLCFA & 0.56 & 0.48 & 0.01 & $<0.001$ & 26.34 & 0.23 \\
\hline BCFA & 2.25 & 2.21 & 0.04 & 0.682 & 32.75 & 0.10 \\
\hline BCFA iso & 1.06 & 0.95 & 0.02 & 0.046 & 31.07 & 0.16 \\
\hline BCFA anteiso & 1.15 & 1.21 & 0.03 & 0.236 & 29.58 & 0.13 \\
\hline OCFA & 3.92 & 4.44 & 0.09 & 0.002 & 19.76 & 0.01 \\
\hline TFA & 3.87 & 9.40 & 0.41 & $<0.001$ & 34.68 & 0.17 \\
\hline \multicolumn{7}{|l|}{ Desaturase index (DI) } \\
\hline DI_14 & 0.09 & 0.14 & 0.01 & $<0.001$ & 67.44 & 0.29 \\
\hline DI_16 & 0.06 & 0.08 & 0.00 & 0.001 & 61.91 & 0.27 \\
\hline DI_18 & 0.74 & 0.78 & 0.01 & $<0.001$ & 31.72 & 0.19 \\
\hline
\end{tabular}

${ }^{1} \operatorname{Rep}=$ mean repeatability between week within lactation; $\mathrm{h}^{2}=$ estimated heritabilities; $\mathrm{TL}=$ total lipids; $\mathrm{SCFA}=$ short-chain fatty acids $(<\mathrm{C} 11) ; \mathrm{MCFA}=$ medium-chain fatty acids $(\mathrm{C} 12-\mathrm{C} 17)$; LCFA = long-chain fatty acids (C18-C19); VLCFA = very long chain fatty acids $(>$ C19); BCFA = branched-chain fatty acids; OCFA $=$ odd-chain fatty acids; TFA $=$ trans fatty acids; DI_14 = C14:1 cis-9/(C14:1 cis-9 + C14:0); DI_16 $=\mathrm{C} 16: 1$ cis-9/(C16:1 cis-9 + C16:0); DI_18 = C18:1 cis-9/(C18:0 + C18:1 cis-9).

Table 3. Correlations between canonical (CAN) and original variables in the 6 wk of the trials

\begin{tabular}{|c|c|c|c|c|c|c|}
\hline \multirow[b]{2}{*}{ Item $^{1}$} & \multicolumn{6}{|c|}{ CAN } \\
\hline & Wk 1 & Wk 2 & Wk 3 & Wk 4 & Wk 5 & Wk 6 \\
\hline \multicolumn{7}{|l|}{ FA related to control group } \\
\hline C18:2 trans -10, trans -12 & 0.583 & 0.564 & -0.531 & -0.367 & -0.372 & 0.712 \\
\hline C18:2 trans-8,trans-10 & 0.360 & 0.314 & -0.375 & -0.375 & -0.368 & 0.333 \\
\hline $\mathrm{C} 18: 2$ trans -11, cis- 13 & 0.428 & 0.411 & -0.366 & -0.320 & -0.374 & 0.493 \\
\hline $\mathrm{C} 18: 2$ cis- 10, cis- 12 & 0.376 & 0.392 & -0.386 & -0.356 & -0.329 & 0.398 \\
\hline C18:2 cis-9,cis-11 & 0.318 & 0.394 & -0.373 & -0.375 & -0.350 & 0.386 \\
\hline $\mathrm{C} 15: 0$ iso & 0.335 & 0.498 & -0.226 & -0.103 & -0.406 & 0.486 \\
\hline \multicolumn{7}{|l|}{ FA related to MFD group } \\
\hline $\mathrm{C} 18: 2$ trans -10, cis -12 & -0.900 & -0.830 & 0.818 & 0.944 & 0.923 & -0.898 \\
\hline $\mathrm{C} 16: 1$ trans $-6-7$ & -0.339 & -0.376 & 0.316 & 0.324 & 0.470 & -0.465 \\
\hline C16:1 trans-9 & -0.375 & -0.459 & 0.436 & 0.444 & 0.780 & -0.538 \\
\hline C18:1 trans- $6-8$ & -0.443 & -0.663 & 0.628 & 0.801 & 0.761 & -0.741 \\
\hline C18:1 trans-9 & -0.391 & -0.386 & 0.645 & 0.786 & 0.727 & -0.731 \\
\hline C18:1 trans-10 & -0.524 & -0.742 & 0.753 & 0.761 & 0.625 & -0.795 \\
\hline C18:1 cis-11 & -0.323 & -0.307 & 0.379 & 0.646 & 0.496 & -0.577 \\
\hline $\mathrm{C} 18: 3$ cis-9,cis-12,cis-15 & -0.364 & -0.505 & 0.324 & 0.589 & 0.628 & -0.435 \\
\hline$\%$ of correct classification into groups & 96 & 100 & 93 & 100 & 98 & 95 \\
\hline
\end{tabular}

${ }^{1} \mathrm{FA}=$ fatty acid; MFD = milk fat depression. 
ing FA: C18:2 trans-10,trans-12, C18:2 trans-8,trans-10, C18:2 trans-11,cis-13, C18:2 cis-10,cis-12, and C15:0 iso. These FA were more associated with control group because they showed higher, in absolute value, correlations with CAN (Table 3) when CC of the control group were positive (wk 1, 2, and 6) and negative (wk 3,4 , and 5), respectively (Table 3 ). On the contrary, the highest, in absolute value, $\mathrm{CC}$ of the second group, constituted by $\mathrm{C} 18: 2$ trans-10, cis-12, C16:1 trans- $6-7$, C16:1 trans-9, C18:1 trans-6-8, C18:1 trans-9, C18:1 trans-10, C18:1 cis-11, and C18:3n-3, were related to the MFD group (Table 3 and Figure 2).

The DA was able to correctly assign most animals to the 2 groups. Errors in assignment ranged from $0 \%$ for wk 2 and 4 to $7 \%$ for wk 3 (Table 3 ): 2, 0, 3, 0, 1, and 2 for wk $1,2,3,4,5$, and 6 , respectively.

\section{DISCUSSION}

According to Bauman and Griinari (2003), MFD is a naturally occurring situation when lactating cows are fed highly fermentable diets or dietary supplements of plant or marine oils. Several studies in the literature have consistently reported that the MFD syndrome is associated with modification of rumen biohydrogenation pathways that result in the production of unique FA intermediates, which are powerful inhibitors of milk fat synthesis (Bauman and Griinari, 2001; Shingfield et al., 2010).

In the present study, a group of cows experiencing MFD was compared with a group of cows in normal condition, with the aim to identify the biohydrogenation products more related to MFD syndrome.

The cows of both groups were in the same herd, received the same diet, and were confined in the same barn with equal access to the ration. Despite this situ-

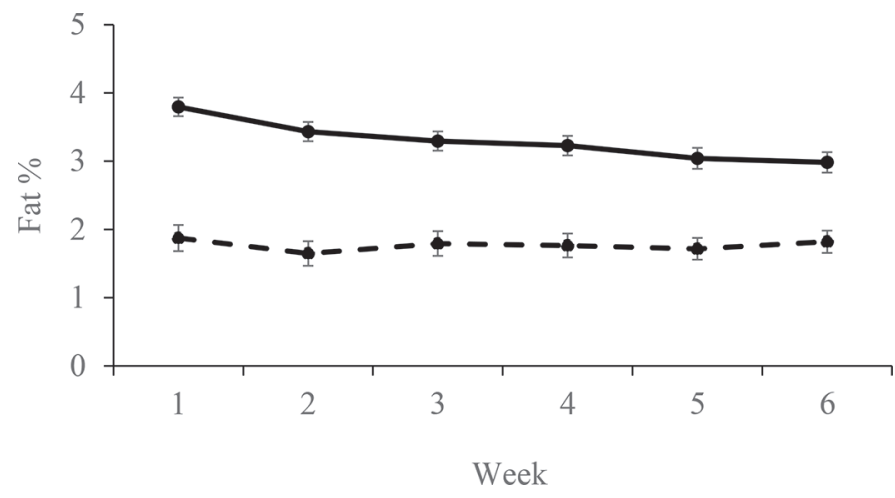

Figure 1. Milk fat percent of control (solid line) and milk fat depression (MFD; dashed line) groups during the 6 wk of the trial. Error bars indicate pooled SEM.

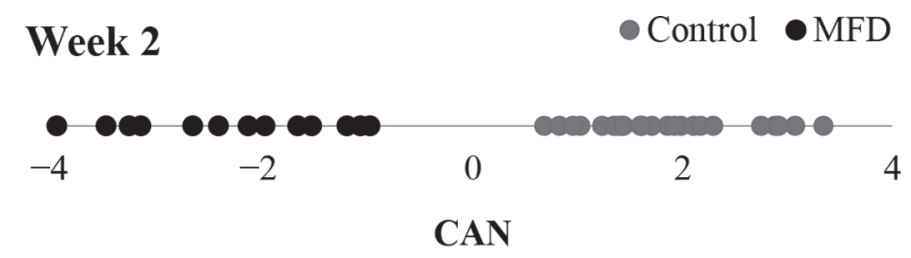

Week 4

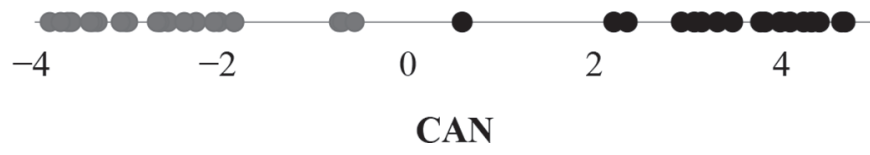

Figure 2. Graph of the canonical function (CAN), for wk 2 and 4, for the control and milk fat depression (MFD) group. The position in the left or right side of the graph is related to negative or positive canonical coefficients, respectively.

ation, cows of the MFD group showed a lower milk fat secretion. This effect was probably related to the level of starch in the diet, which was higher than $22 \%$ of DMI, and is demonstrated to be a minimum threshold to create favorable conditions for MFD, considerably reducing the level of $\mathrm{pH}$, as demonstrated by Ramirez Ramirez et al. (2015). Therefore, we hypothesized that feeding high starch content in a TMR may predispose cows to undergo MFD due to altered ruminal fermentation and acidosis (Ramirez Ramirez et al., 2015). Furthermore, Ramirez Ramirez et al. (2015) suggested that fat supplementation would intensify this response by altering biohydrogenation of PUFA. In the present work, the diet was not supplemented with fat, which would have likely exacerbated the extent and number of cows experiencing MFD. Cows of the MFD group were probably more susceptible to rumen $\mathrm{pH}$ modification and then to MFD. Cows belonging to the MFD group experienced the low milk fat syndrome at different lactation stages and parity. Moreover, based on the information collected during the experimental period, another possible hypothesis to explain the MFD is related to a particular feeding behavior of the animals, that they are more able to select specific ingredients of the TMR (i.e., grain and pelleted concentrate).

Because this was an observational study, milk samples were collected starting from the first cases of MFD and no milk samples relative to the period before the putative MFD were available. For this reason, all the comparisons were referred to the control group to identify a milk FA pattern able to suggest potential rumen metabolic pathways associated with MFD.

The rumen environment has been shown to have a relevant role to define milk fat synthesis, as a consequence of biohydrogenation activity and VFA synthesis (Buc- 
cioni et al., 2012). This consideration was confirmed by the high level of variance $(>60 \%)$ explained by rumen activity on milk FA profile. Moreover, the proportion of variance explained by the animal for rumen FA was lower than 0.3 , confirming that the different behavior of rumen activity observed between the 2 groups was related to the different rumen environment caused by the diet or other external factors.

The repeatability of test day values within lactation for all the studied components ranged from 0.05 to $84.16 \%$ (Table 2). The results agree with previous reports (Bormann et al., 2003; Gengler et al., 2004; Soyeurt et al., 2006, 2007). High level of repeatability (>60\%) was observed for protein \%, C14:1 cis-9, C16:1 cis-9, C18:2 trans-11,cis-15, some CLA isomers, and 2 DI (DI_14 and DI_16).

This trend was confirmed by the high level of estimated heritability for all FA involved in the mammary lipid metabolism (Table 2), whereas those deriving from rumen activity showed low value as consequence of a lower effect of genetic component. Our data were higher than those observed by Mele et al. (2009), but similar to the results obtained by Stoop et al. (2008). Surely, the greater homogeneity on environmental effects in our study and Stoop et al. (2008) can be the principal reason for this difference with the Mele et al. (2009) results. Moreover, our study was based on a limited number of cows with respect to Mele et al. (2009), which led to larger standard errors of genetic estimates.

However, these data suggest a relevant importance of the animal effect. It is interesting to note that most of these parameters are related to $\Delta^{9}$-desaturase activity, which is little influenced by the environment. Conversely, genetic component significantly affects desaturase activity, due to the central role of the $S C D$ gene in mammalian lipid metabolism (Mele et al., 2007). Heritability values for DI_14, DI_16, and DI_18 were higher than 0.20, with DI_14 showing the greatest value, confirming what had been reported by Schennink et al. (2008) and Mele et al. (2009). The DI_14 ratio has been suggested as the best indicator for the $S C D$ activity (Lock and Garnsworthy, 2003; Mele et al., 2009): C14:0 in milk fat derives almost exclusively from de novo synthesis in the mammary gland, and therefore, almost all of the C14:1 cis-9 is likely to be synthesized by $S C D$ (Bernard et al., 2006).

Cows of MFD group showed a significant lower level of fat secretion $(-50 \%$, which was considered one of the parameters for MFD diagnosis, as proposed by Griinari et al. (1998; Table 2), without modification of milk yield, protein, and lactose secretion (Table 2). This pattern was consistent with those previously described in experiments aimed to induce MFD in dairy cows (Shingfield and Griinari, 2007; Harvatine et al., 2009).
By comparing FA composition of milk from MFD cows with that from the control group, a lower secretion of de novo FA was observed, confirming that in dairy cows MFD is associated with a reduction of milk fat synthesis by the inhibition of the metabolism associated with de novo FA synthesis (Table 2) (Baumgard et al., 2002; Suárez-Vega et al., 2017).

The reduction of lipogenic metabolism was related to an inhibition effect on ACACA, ACSS2, FABP3, FASN, and $L P L$ genes, which are involved in mammary lipid neo-synthesis (Kadegowda et al., 2008). This mechanism could explain the FA decrease observed in milk from MFD cows in the almost all FA involved in the mammary lipid metabolism (Table 2).

On the other hand, an increase of the activity of stearoyl CoA desaturase (SCD) was suggested by the higher level of DI in MFD cows (Table 2). Desaturase indexes, in fact, are considered a proxy for SCD activity (Mele et al., 2007). Previous works revealed a significant reduction of $S C D$ expression in the mammary gland from dairy cows affected by MFD (Peterson et al., 2003; Kadegowda et al., 2008; Gervais et al., 2009). In some experiments with goats, diet supplemented with fat reduced $S C D$ expression, but no effect was observed on DI (Bernard et al., 2009a,b). Other studies demonstrated that changes in the DI values were not associated with MFD (Shingfield et al., 2008). Probably, the values of DI are regulated by factors other than $S C D$ activity, including differential uptake, turnover, and utilization of FA substrates in mammary tissue (Shingfield et al., 2010). Multivariate factor analysis on cow milk revealed that desaturation activity was explained by different factors, as a consequence of different regulation pathways (Conte et al., 2016; Mele et al., 2016). Probably, MFD syndrome causes a modification of milk FA profile, which needs regulation of $S C D$ activity. In fact, it is well demonstrated that $S C D$ activity regulates the milk fat fluidity by synthesis of C18:1 cis-9 starting from C18:0 (Jacobs et al., 2013). Modification of the C18:1 cis-9/C18:0 ratio, as a consequence of external factors, causes problems to the cell membrane structure, so $S C D$ plays a critical role in maintaining fluidity of cell membranes as well as milk fat, preventing cellular disorders. Fluidity of FA is determined primarily by FA chain length and by the amount and orientation of double bonds. Therefore, the profile of FA available for the synthesis of milk fat triglycerides may affect fluidity (Jacobs et al., 2013), coupled with other factors like positioning of FA on triglyceride, specifically the sn-3 position. The reduction of C18:0 outflow from rumen and the contemporary increase of trans C18:1 may induce a regulation of the milk fat melting point (Loor et al., 2005; Gama et al., 2008). Changes in DI observed in the present work may be a consequence of 
modification in the melting point, which, in turn, may alter the secretion of triglycerides from the mammary epithelial cells. However, this supposition needs more investigation because it is unclear what is the biological mechanism regulating $S C D$ differently than the other lipogenic genes.

As reported in Table 2, milk from MFD cows had a different CLA isomers profile compared with that from control cows. Changes in the content of C18:2 trans-10,cis-12 were consistent with previous findings reporting that in dairy cows the increase in C18:2 trans10, cis-12 in milk fat was associated with a shift in the rumen biohydrogenation pathways, as a consequence of the administration of high starch diets (Shingfield et al., 2010). Although rumenic acid (C18:2 cis-9,trans-11) was the most abundant CLA isomer in milk from both groups, the level of C18:2 trans-10,cis-12 increases so significantly in the MFD group that its level is almost comparable to that of $\mathrm{C} 18: 2$ cis-9,trans-11, probably as a consequence of the shift of the rumen biohydrogenation pathway toward C18:2 trans-10,cis-12 (Shingfield et al., 2010).

Milk from cows of the MFD group showed a significantly higher content of precursors (C18:2 cis-9,cis-12 and $\mathrm{C} 18: 3$ cis-9,cis-12,cis-15) and intermediates (both C18:2 and C18:1 isomers) of the rumen biohydrogenation process. This result was associated with a significant lower content of C18:0, which is the final product of biohydrogenation (Table 3). Altogether, these differences in the milk FA pattern suggested that cows from the MFD group experienced both a shift and a reduction of biohydrogenation metabolism.

The content of BCFA iso and OCFA was respectively lower and higher in milk fat from MFD cows compared with control cows (Table 2). The content of starch and fiber in the diet plays a central role in BCFA and OCFA synthesis (Bas et al., 2003; Vlaeminck et al., 2004; Cabrita et al., 2009), being associated with changes in the rumen microbial population and metabolism (Vlaeminck et al., 2006). Previous studies reported a significant association between increasing concentration of OCFA in milk fat and the presence of highly degradable starch in the diet (Vlaeminck et al., 2006). Starch fermenting bacteria are able to actively produce propionate, which represents the precursor of the main OCFA (i.e., C13:0, C15:0, and C17:0). The high content of dietary starch was associated with a contemporary reduction of cellulolytic bacteria, which are associated with BCFA iso synthesis (Fievez et al., 2003; Kim et al., 2005). Although the 2 groups were fed the same diet, the differences in the proportion of OCFA and BCFA iso in milk fat between MFD and control cows suggested that MFD cows likely selected specific starch-rich ingredients of the TMR, causing a perturbation in the rumen microbiome composition. Milk OCFA and BCFA, in fact, have been found strictly related to changes in the rumen microbe population (Buccioni et al., 2012). Hence, in the specific conditions realized in the present work, the relative content of OCFA and BCFA in milk fat could be considered as a marker of rumen dysfunctions due to a reduction of rumen $\mathrm{pH}$, and as a consequence high starch level intake or rumen environment of an individual cow. Because we did not measure the intake, the last hypothesis was only a supposition.

Several studies have demonstrated that some C18:1 trans and CLA isomers may cause MFD in dairy cows when their content in milk fat reach a specific threshold (Piperova et al., 2002; Loor et al., 2004; Shingfield et al., 2010). However, none of the candidate FA was able to singularly explain the total decrease in milk fat secretion (Kadegowda et al., 2008). As a consequence, it was proposed that MFD may be the result of a contemporary effect of different biohydrogenation products (Kadegowda et al., 2008). The hypothesis of the present work was that a specific milk FA pattern could be able to discriminate MFD and control cows. With this aim, the CDA was developed, including in the analysis only the milk FA deriving from rumen metabolism. To our knowledge, this is the first time that CDA was used to study the association between milk FA composition and MFD syndrome. Canonical discriminant analysis is a multivariate analysis that evaluates the ability of a pool of variables to discriminate samples previously classified in different groups. In this work, the suitable group of ruminal FA able to highlight the 2 groups (control vs. MFD group) was obtained by using the SDA, which selected 14 of the 37 ruminal FA detected in milk. This result indicates that differences in ruminal $\mathrm{FA}$ profile between the 2 groups of cows are mainly related only to few important FA. Among them, the SDA selected many of the CLA and C18:1 isomers (Table 3) to discriminate cows with MFD, confirming that several FA other than C18:2 trans-10,cis-12 originating by rumen metabolism concurred to affect milk fat synthesis (Kadegowda et al., 2008). However, C18:2 trans-10,cis-12 and $\mathrm{C} 18: 1$ trans-10 showed the highest correlation with CAN and belonged to a group of FA explaining MFD cows' discrimination. This result confirmed the hypothesis that rumen synthesis of these FA is the principal pathway affecting MFD. In normal conditions, vaccenic acid (C18:1 trans-11) is the major intermediate of ruminal biohydrogenation, whereas cows in MFD showed a shift in this pathway replacing large part of C18:1 trans-11 with C18:1 trans-10 (Piperova et al., 2002; Loor et al., 2004; Shingfield et al., 2012). This shift has 
been observed when dairy cows were fed with a high starch diet (Kadegowda et al., 2008; Shingfield et al., 2009). However, the content of C18:1 trans-10 in milk fat $(5.6 \mathrm{~g} / 100 \mathrm{~g}$ of TL$)$ was lower than that reported by Shingfield et al. (2009; $10 \mathrm{~g} / 100 \mathrm{~g}$ of TL) in milk from cows affected with MFD after abomasal infusion of a different kind of C18:1 and C18:2 isomers. Among the FA associated with MFD, C18:1 trans-6-trans-8 and C18:1 trans-9 showed a strong negative correlation with milk fat yield, as also demonstrated in previous works (Loor et al., 2005; Kadegowda et al., 2008). It is worth noting that the milk content of C18:1 trans-9 was lower than that proposed by Kadegowda et al. (2008) to induce MFD (0.49 vs. 0.86; Table 2). Hence, the results of the present research suggested that alternative biohydrogenation pathways involving specific trans C18:1 isomers play a significant role in MFD; however, the pattern of C18:1 trans seemed to be more explicative than the content of an individual isomer.

Five CLA isomers (C18:2 trans-10,trans-12, C18:2 trans-8,trans-10, C18:2 trans-11,cis-13, C18:2 cis10,cis-12, and C18:2 cis-9,cis-11) were more strongly associated with control cows, suggesting that some collateral biohydrogenation pathways resulting in CLA isomers different from C18:2 cis-9,trans-11 are probably activated in normal rumen conditions, as previously described by Shingfield et al. (2010). All the 5 CLA isomers derived by an isomerization of C18:2n- 6 and were biohydrogenated to the relative C18:1 isomer (Shingfield et al., 2010): C18:1 trans-10 (from C18:2 trans-10,trans-12), C18:1 trans-8 (from C18:2 trans8,trans-10), C18:1 cis-13 (from C18:2 trans-11,cis-13), C18:1 cis-12 (from C18:2 cis-10,cis-12), and C18:1 cis11 (from C18:2 cis-9,cis-11). Because these CLA isomers were positively associated with control cows and negatively with MFD cows, their content in the milk could be a specific pattern associated with changes in rumen biohydrogenation pathways of C18:2n-6.

The C15:0 iso was the only BCFA selected for CDA, showing a high aptitude to discriminate between the 2 groups (Table 3 ) because of the strong association with control cows. The CDA revealed that MFD syndrome was associated with a modification in the pattern of milk FA deriving from microbial lipid metabolism in the rumen. As known, rumen bacterial population can be divided in bacteria present in the liquid phase and bacteria loosely and firmly attached to feed particles (Buccioni et al., 2012). These 3 categories of bacteria showed a different lipid metabolism, as demonstrated by numerous works (Buccioni et al., 2012). In fact, each of these bacterial fractions produces a higher proportion of specific FA:OCFA (liquid phase bacteria), C18:1 trans isomers (bacteria firmly attached to feed particles), and BCFA iso (bacteria loosely attached to feed particles; Bessa et al., 2009). It is interesting to evaluate, with further investigations, if the different amount of the OCFA and BCFA may be related to a different composition of bacteria population.

Between the FA selected by CDA, there were C16:1 trans isomers (C16:1 trans- $6-7$ and C16:1 trans-9). As reported in Table 2, these FA were significantly higher in milk from MFD cows. The occurrence of these FA in milk is not thought to be related to the diet. In fact, because the content of $\mathrm{C} 16: 1$ cis isomers in the diet is usually very low, their isomerization or hydrogenation (or both) in the rumen has been considered very unlikely (Luna et al., 2009). Probably, they could originate from the $\beta$-oxidation by a single step 2-carbon shortening of the C18:1 trans FA (Osmundsen et al., 1991), as also suggested by the high and significant correlation observed (0.66, $P<0.001)$ between $\mathrm{C} 16: 1$ and $\mathrm{C} 18: 1$ trans isomers. According to this hypothesis, the prevalence of the C16:1 trans-9 among 16:1 trans isomers could be related to the prevalence of its substrate, C18:1 trans-11, among C18:1 trans isomers. The higher amount of these isomers in milk from MFD cows, and their high correlation with the CAN variables, suggested that milk C16:1 trans isomers could be a further element to explain the MFD status. This could be due to the high amount of their substrates (C18:1 trans) in milk from MFD cows. Further studies are needed to evaluate if higher levels of C16:1 trans in milk from MFD cows could be related also to changes in FA $\beta$-oxidation in the animal tissues.

Some of the selected variables (C18:2 trans-8, trans-10, $\mathrm{C} 18: 2$ trans-11,cis-13, C18:2 cis-10,cis-12, and C18:2 cis-9,cis-11) did not differ between groups in the ANOVA model used. This is a plausible result, as the SDA is a multivariate technique. This procedure, at each step, reviews and evaluates all involved variables to determine which one contributes most to the discrimination between groups. The contribution of the single variable is evaluated in relation to the others to delineate the optimal variable profile to separate the groups. As a consequence, a variable that is not significant for group separation in the univariate approach could be important in the multivariate sense.

\section{CONCLUSIONS}

The unexpected MFD observed in cows maintained in a commercial dairy farm gave us the opportunity to carry out an a posteriori study by adopting a multivariate approach to extract data of milk FA composition, with special focus on FA deriving from rumen metabolism. Results confirmed that specific milk FA patterns can be associated with MFD status, providing a set 
of potential markers of MFD. The presence of these patterns also suggested that MFD was a consequence of modifications of the rumen metabolism, which led to the outflow of particular FA having, all together, a depressive effect on mammary fat synthesis. The multivariate approach confirmed that this type of analysis can be a useful tool to evaluate a metabolic pathway that involves several parameters. This approach provided interesting suggestions about the role of some FA, allowing to focus on the metabolism that affects MFD. Molecular investigation are needed to confirm these results, giving a clearer interpretation of this syndrome.

\section{ACKNOWLEDGMENTS}

This research was supported by a Regione Toscana (Italy) grant, CASET-project "Caratterizzazione AgroAmbientale, Socio-Economica e Territoriale del latte Mugello," PSR 2007-2013.

\section{REFERENCES}

Alizadeh, A. R., M. Alikhani, G. R. Ghorbani, H. R. Rahmani, L. Rashidi, and J. J. Loor. 2012. Effects of feeding roasted safflower seeds (variety IL-111) and fish oil on dry matter intake, performance and milk fatty acid profiles in dairy cattle. J. Anim. Physiol. Anim. Nutr. (Berl.) 96:466-473.

Angulo, J., L. Mahecha, K. Nuernberg, G. Nuernberg, D. Dannenberger, M. Olivera, M. Boutinaud, C. Leroux, E. Albrecht, and L. Bernard. 2012. Effects of polyunsaturated fatty acids from plant oils and algae on milk fat yield and composition are associated with mammary lipogenic and SREBF1 gene expression. Animal 6:1961-1972.

Bas, P., H. Archimede, A. Rouzeau, and D. Sauvant. 2003. Fatty acid composition of mixed-rumen bacteria: Effect of concentration and type of forage. J. Dairy Sci. 86:2940-2948.

Bauman, D. E., and J. M. Griinari. 2001. Regulation and nutritional manipulation of milk fat: Low-fat milk syndrome. Livest. Prod. Sci. 70:15-29.

Bauman, D. E., and J. M. Griinari. 2003. Nutritional regulation of milk fat synthesis. Annu. Rev. Nutr. 23:203-227.

Bauman, D. E., K. J. Harvatine, and A. L. Lock. 2011. Nutrigenomics, rumen-derived bioactive fatty acids, and the regulation of milk fat synthesis. Annu. Rev. Nutr. 31:299-319.

Baumgard, L. H., B. A. Corl, D. A. Dwyer, A. Saebo, and D. E. Bauman. 2000. Identification of the conjugated linoleic acid isomer that inhibits milk fat synthesis. Am. J. Physiol. Regul. Integr. Comp. Physiol. 278:R179-R184.

Baumgard, L. H., E. Matitashvili, B. A. Corl, D. A. Dwyer, and D. E. Bauman. 2002. Trans-10, cis-12 conjugated linoleic acid decreases lipogenic rates and expression of genes involved in milk lipid synthesis in dairy cows. J. Dairy Sci. 85:2155-2163.

Bernard, L., C. Leroux, and Y. Chilliard. 2006. Characterization and nutritional regulation of the main genes in the lactating mammary gland. Pages 295-326 in Ruminant Physiology. K. Sejrsen, T. Hvelplund, and M. O. Nielsen, ed. Wageningen Academic Publisher, Wageningen, the Netherlands.

Bernard, L., C. Leroux, Y. Faulconnier, D. Durand, K. J. Shingfield, and Y. Chilliard. 2009a. Effect of sunflower-seed oil or linseed oil on milk fatty acid secretion and lipogenic gene expression in goats fed hay-based diets. J. Dairy Res. 76:241-248.

Bernard, L., K. J. Shingfield, J. Rouel, A. Ferlay, and Y. Chilliard. 2009b. Effect of plant oils in the diet on performance and milk fatty acid composition in goats fed diets based on grass hay or maize silage. Br. J. Nutr. 101:213-224.

Bessa, R. J. B., M. R. G. Maia, E. Jerónimo, A. T. Belo, A. R. J. Cabrita, R. J. Dewhurst, and A. J. M. Fonseca. 2009. Using microbial fatty acids to improve understanding of the contribution of solid associated bacteria to microbial mass in the rumen. Anim. Feed Sci. Technol. 150:197-206.

Bichi, E., P. Frutos, P. G. Toral, D. Keisler, G. Hervás, and J. J. Loor. 2013. Dietary marine algae and its influence on tissue gene network expression during milk fat depression in dairy ewes. Anim. Feed Sci. Technol. 186:36-44.

Bionaz, M., J. Osorio, and J. J. Loor. 2015. Nutrigenomics in dairy cows: Nutrients, transcription factors, and techniques. J. Anim. Sci. 93:5531-5553.

Bormann, J., G. R. Wiggans, T. Druet, and N. Gengler. 2003. Withinherd effects of age at test-day and lactation stage on test-day yields. J. Dairy Sci. 86:3765-3774.

Buccioni, A., M. Decandia, S. Minieri, G. Molle, and A. Cabiddu. 2012. Lipid metabolism in the rumen: New insights on lipolysis and biohydrogenation with an emphasis on the role of endogenous plant factors. Anim. Feed Sci. Technol. 174:1-25.

Cabrita, A. R. J., J. M. P. Vale, R. J. B. Bessa, R. J. Dewhurst, and A. J. M. Fonseca. 2009. Effects of dietary starch source and buffers on milk responses and rumen fatty acid biohydrogenation in dairy cows fed maize silage-based diets. Anim. Feed Sci. Technol. 152:267-277.

Conte, G., A. Serra, P. Cremonesi, S. Chessa, B. Castiglioni, A. Cappucci, E. Bulleri, and M. Mele. 2016. Investigating mutual relationship among milk fatty acids by multivariate factor analysis in dairy cows. Livest. Sci. 188:124-132.

De Maesschalck, R., D. Jouan-Rimbaud, and D. L. Massart. 2000. The Mahalanobis distance. Chemometr. Intell. Lab. 50:1-18.

Fievez, V., B. Vlaeminck, M. S. Dhanoa, and R. J. Dewhurst. 2003 Use of principal component analysis to investigate the origin of heptadecanoic and conjugated linoleic acids in milk. J. Dairy Sci 86:4047-4053.

Gama, M. A. S., P. C. Gamsworthy, J. M. Griinari, P. R. Leme, P. H. M. Rodrigues, L. W. O. Souza, and D. P. D. Lanna. 2008. Dietinduced milk fat depression: Association with changes in milk fatty acid composition and fluidity of milk fat. Livest. Sci. 115:319-331.

Gengler, N., G. R. Wiggans, and A. Gillon. 2004. Estimated heterogeneity of phenotypic variance of test-day yield with a structural variance model. J. Dairy Sci. 87:1908-1916.

Gervais, R., J. W. McFadden, A. J. Lengi, B. A. Corl, and P. Y. Chouinard. 2009. Effects of intravenous infusion of trans-10, cis-12 18:2 on mammary lipid metabolism in lactating dairy cows. J. Dairy Sci. 92:5167-5177.

Griinari, J. M., D. A. Dwyer, M. A. McGuire, D. E. Bauman, D. L. Palmquist, and K. V. V. Nurmela. 1998. Trans-octadecenoic acids and milk fat depression in lactating dairy cows. J. Dairy Sci. $81: 1251-1261$.

Harvatine, K. J., and D. E. Bauman. 2011. Characterization of the acute lactational response to trans-10, cis-12 conjugated linoleic acid. J. Dairy Sci. 94:6047-6056.

Harvatine, K. J., Y. R. Boisclair, and D. E. Bauman. 2009. Recent advances in the regulation of milk fat synthesis. Animal 3:40-54.

Hussein, M., K. H. Harvatine, W. M. P. B. Weerasinghe, L. A. Sinclair, and D. E. Bauman. 2013. Conjugated linoleic acid-induced milk fat depression in lactating ewes is accompanied by reduced expression of mammary genes involved in lipid synthesis. J. Dairy Sci. 96:3825-3834.

ISO. 2013. ISO9622. Milk and milk liquid products-Guidelines for the application of mid-infrared spectrometry. The International Organization for Standardization, Geneva, Switzerland.

Jacobs, A. A. A., J. Dijkstra, J. S. Liesman, M. J. VandeHaar, A. L. Lock, A. M. van Vuuren, W. H. Hendriks, and J. van Baal. 2013 Effects of short- and long-chain fatty acids on the expression of stearoyl-CoA desaturase and other lipogenic genes in bovine mammary epithelial cells. Animal 7:1508-1516. 
Kadegowda, A. K. G., L. S. Piperova, and R. A. Erdman. 2008. Principal component and multivariate analysis of milk long-chain fatty acid composition during diet-induced milk fat depression. J. Dairy Sci. 91:749-759.

Kargar, S., G. R. Ghorbani, M. Alikhani, M. Khorvash, L. Rashidi, and D. J. Schingoethe. 2012. Lactational performance and milk fatty acid profile of Holstein cows in response to dietary fat supplements and forage:concentrate ratio. Livest. Sci. 150:274-283.

Kim, E. J., R. Sanderson, M. S. Dhanoa, and R. J. Dewhurst. 2005. Fatty acid profiles associated with microbial colonization of freshly ingested grass and rumen biohydrogenation. J. Dairy Sci. 88:32203230 .

Kramer, J. K. G., C. Cruz-Hernandez, Z. Y. Deng, J. Q. Zhou, G. Jahreis, and M. E. R. Dugan. 2004. Analysis of conjugated linoleic acid and trans 18:1 isomers in synthetic and animal products. Am. J. Clin. Nutr. 79:1137S-1145S.

Kramer, J. K. G., M. Hernández, C. Cruz-Hernández, J. Kraft, and M. E. R. Dugan. 2008. Combining results of two GC separations partly achieves determination of all cis and trans 16:1, 18:1, 18:2 and 18:3 except CLA isomers of milk fat as demonstrated using Ag-ion SPE fractionation. Lipids 43:259-273.

Lock, A. L., and P. C. Garnsworthy. 2003. Seasonal variation in milk conjugated linoleic acid and $\Delta 9$ desaturase activity in dairy cows. Livest. Prod. Sci. 79:47-59.

Lock, A. L., C. Tyburczy, D. A. Dwyer, K. J. Havartine, F. Destaillats, Z. Mouloungui, L. Candy, and D. E. Bauman. 2007. Trans-10 octadecenoic acid does not reduce milk fat synthesis in dairy cows. J. Nutr. 137:71-76.

Loor, J. J., A. Ferlay, A. Ollier, K. Ueda, M. Doreau, and Y. Chilliard. 2005. High-concentrate diets and polyunsaturated oils alter trans and conjugated isomers in bovine rumen, blood, and milk. J. Dairy Sci. 88:3986-3999.

Loor, J. J., K. Ueda, A. Ferlay, Y. Chilliard, and M. Doreau. 2004. Biohydrogenation, duodenal flow, and intestinal digestibility of trans fatty acids and conjugated linoleic acids in response to dietary forage concentrate ratio and linseed oil in dairy cows. J. Dairy Sci. 87:2472-2485.

Luna, P., V. Rodríguez-Pino, and M. A. de la Fuente. 2009. Occurrence of $\mathrm{C} 16: 1$ isomers in milk fats from ewes fed with different dietary lipid supplements. Food Chem. 117:248-253.

Macciotta, N. P., S. Biffani, U. Bernabucci, N. Lacetera, A. Vitali, P. Ajmone-Marsan, and A. Nardone. 2017. Derivation and genomewide association study of a principal component-based measure of heat tolerance in dairy cattle. J. Dairy Sci. 100:4683-4697.

Mardia, K. V. 1975. Assessment of multinormality and robustness of Hotelling's T2 test. Appl. Stat. 24:163-171.

Mardia, K. V., F. L. Bookstein, and I. J. Moreton. 2000. Statistical assessment of bilateral symmetry of shapes. Biometrika 87:285-300.

McKain, N., K. J. Shingfield, and R. J. Wallace. 2010. Metabolism of conjugated linoleic acids and 18:1 fatty acids by ruminal bacteria: Products and mechanisms. Microbiology 156:579-588.

Medeiros, S. R., D. E. Oliveira, L. J. Aroeira, M. A. McGuire, D. E. Bauman, and D. P. Lanna. 2010. Effects of dietary supplementation of rumen-protected conjugated linoleic acid to grazing cows in early lactation. J. Dairy Sci. 93:1126-1137.

Mele, M., G. Conte, B. Castiglioni, S. Chessa, N. P. P. Macciotta, A. Serra, A. Buccioni, G. Pagnacco, and P. Secchiari. 2007. StearoylCoA desaturase gene polymorphism and milk fatty acid composition in Italian Friesian cows. J. Dairy Sci. 90:4458-4465.

Mele, M., R. Dal Zotto, M. Cassandro, G. Conte, A. Serra, A. Buccioni, G. Bittante, and P. Secchiari. 2009. Genetic parameters for conjugated linoleic acid, selected milk fatty acids, and milk fatty acid unsaturation of Italian Holstein-Friesian cows. J. Dairy Sci. 92:392-400.

Mele, M., N. P. P. Macciotta, A. Cecchinato, G. Conte, S. Schiavon, and G. Bittante. 2016. Multivariate factor analysis of detailed milk fatty acid profile: Effects of dairy system, feeding, herd, parity, and stage of lactation. J. Dairy Sci. 99:9820-9833.

Mele, M., A. Serra, A. Buccioni, G. Conte, A. Pollicardo, and P. Secchiari. 2008. Effect of soybean oil supplementation on milk fatty acid composition from Saanen goats fed diets with different forage: concentrate ratios. Ital. J. Anim. Sci. 7:297-311.

Mohammed, R., J. J. Kennelly, J. K. G. Kramer, K. A. Beauchemin, C. S. Stanton, and J. J. Murphy. 2010. Effect of grain type and processing method on rumen fermentation and milk rumenic acid production. Animal 4:1425-1444.

Osmundsen, H., J. Bremer, and J. I. Pedersen. 1991. Metabolic aspects of peroxisomal b-oxidation. Biochim. Biophys. Acta 1085:141-158.

Peterson, D. G., E. A. Matitashvili, and D. E. Bauman. 2003. Diet-induced milk fat depression in dairy cows results in increased trans-10, cis-12 CLA in milk fat and coordinate suppression of mRNA abundance for mammary enzymes involved in milk fat synthesis. J. Nutr. 133:3098-3102.

Piperova, L. S., J. Sampugna, B. B. Teter, K. F. Kalschgeur, M. P. Yurawecz, Y. Ku, K. M. Morehouse, and R. A. Erdman. 2002. Duodenal and milk trans octadecenoic acid and conjugated linoleic acid (CLA) isomers indicate that postabsorptive synthesis is the predominant source of cis-9-containing CLA in lactating dairy cows. J. Nutr. 132:1235-1241.

Ramirez Ramirez, H. A.. E. Castillo Lopez, K. J. Harvatine, and P. J. Kononoff. 2015. Fat and starch as additive risk factors for milk fat depression in dairy diets containing corn dried distillers grains with solubles. J. Dairy Sci. 98:1903-1914.

Rico, D. E., and K. J. Harvatine. 2013. Induction of and recovery from milk fat depression occurs progressively in dairy cows switched between diets that differ in fiber and oil concentration. J. Dairy Sci. 96:6621-6630.

Roy, A., A. Ferlay, K. J. Shingfield, and Y. Chilliard. 2006. Examination of the persistency of milk fatty acid composition responses to plant oils in cows given different basal diets, with particular emphasis on trans-C18:1 fatty acids and isomers of conjugated linoleic acid. Anim. Sci. 82:479-492.

Schennink, A., J. M. Heck, H. Bovenhuis, M. H. P. W. Visker, H. J. F. van Valenberg, and J. A. M. van Arendonk. 2008. Milk fatty acid unsaturation: Genetic parameters and effects of stearoyl-CoA desaturase (SCD1) and acyl CoA: diacylglycerol acyltransferase 1 (DGAT1). J. Dairy Sci. 91:2135-2143.

Shingfield, K. J., A. Ärölä, S. Ahvenjärvi, A. Vanhatalo, V. Toivonen, J. M. Griinari, and P. Huhtanen. 2008. Ruminal infusions of cobalt-EDTA reduce mammary D9-desaturase index and alter milk fatty acid composition in lactating cows. J. Nutr. 138:710-717.

Shingfield, K. J., L. Bernard, C. Leroux, and Y. Chilliard. 2010. Role of trans fatty acids in the nutritional regulation of mammary lipogenesis in ruminants. Animal 4:1140-1166.

Shingfield, K. J., and J. M. Griinari. 2007. Role of biohydrogenation intermediates in milk fat depression. Eur. J. Lipid Sci. Technol. 109:799-816

Shingfield, K. J., P. Kairenius, A. Ärölä, D. Paillard, S. Muetzel, S. Ahvenjärvi, A. Vanhatalo, P. Huhtanen, V. Toivonen, J. M. Griinari, and R. J. Wallace. 2012. Dietary fish oil supplements modify ruminal biohydrogenation, alter the flow of fatty acids at the omasum, and induce changes in the ruminal Butyrivibrio population in lactating cows. J. Nutr. 142:1437-1448.

Shingfield, K. J., C. K. Reynolds, G. Hervás, J. M. Griinari, A. S. Grandison, and D. E. Beever. 2006. Examination of the persistency of milk fatty acid composition responses to fish oil and sunflower oil in the diet of dairy cows. J. Dairy Sci. 89:714-732.

Shingfield, K. J., A. Sæbø, P.-C. Sæbø, V. Toivonen, and J. M. Griinari. 2009. Effect of abomasal infusions of a mixture of octadecenoic acids on milk fat synthesis in lactating cows. J. Dairy Sci. 92:4317-4329.

Soyeurt, H., P. Dardenne, A. Gillon, C. Croquet, S. Vanderick, P. Mayeres, C. Bertozzi, and N. Gengler. 2006. Variation in fatty acid contents of milk and milk fat within and across breeds. J. Dairy Sci. 89:4858-4865.

Soyeurt, H., A. Gillon, S. Vanderick, P. Mayeres, C. Bertozzi, and N. Gengler. 2007. Estimation of heritability and genetic correlations for the major fatty acids in bovine milk. J. Dairy Sci. 90:44354442 . 
Stoop, W. M., J. A. M. van Arendonk, J. M. L. Heck, H. J. F. van Valenberg, and H. Bovenhuis. 2008. Genetic parameters for major milk fatty acids and milk production traits of Dutch HolsteinFriesians. J. Dairy Sci. 91:385-394.

Suárez-Vega, A., P. G. Toral, B. Gutiérrez-Gil, G. Hervás, J. J. Arranz, and P. Frutos. 2017. Elucidating fish oil-induced milkfat depression in dairy sheep: Milk somatic cell transcriptome analysis. Sci. Rep. https://doi.org/10.1038/srep45905.

Toral, P. G., G. Hervás, D. Carreño, A. Belenguer, and P. Frutos, 2015. Comparison of milk fatty acid responses during fish oil- and trans-10 cis-12 18:2-induced milk fat depression in dairy ewes. Anim. Feed Sci. Technol. 210:66-73.

Ventto, L., H. Leskinen, P. Kairenius, T. Stefanski, A. R. Bayat, J. Vilkki, and K. J. Shingfield. 2017. Diet-induced milk fat depression is associated with alterations in ruminal biohydrogenation pathways and formation of novel fatty acid intermediates in lactating cows. Br. J. Nutr. 117:364-376. https://doi.org/10.1017/ S0007114517000010.

Vlaeminck, B., V. Fievez, A. R. J. Cabrita, A. J. M. Fonseca, and R. J. Dewhurst. 2006. Factors affecting odd- and branched-chain fatty acids in milk: A review. Anim. Feed Sci. Technol. 131:389-417.

Vlaeminck, B., V. Fievez, H. van Laar, and D. Demeyer. 2004. Rumen odd and branched chain fatty acids in relation to in vitro rumen volatile fatty acid productions and dietary characteristics of incubated substrates. J. Anim. Physiol. Anim. Nutr. (Berl.) 88:401-411.

Wallace, R. J., N. McKain, K. J. Shingfield, and E. Devillard. 2007. Isomers of conjugated linoleic acids are synthesized via different mechanisms in ruminal digesta and bacteria. J. Lipid Res. $48: 2247-2254$ 